\title{
Predicting leaf litter decomposability: an exploratory assessment of leaf traits, litter traits and spectral properties in six Mediterranean herbaceous species
}

\author{
Natalia Pérez-Harguindeguy ${ }^{1, \otimes}$; Jacques Cortez²; Eric Garnier²; Dominique Gillon² \& \\ MARÍA POCA ${ }^{1}$
}

1. Instituto Multidisciplinario de Biología Vegetal (CONICET-Universidad Nacional de Córdoba) and Facultad de Ciencias Exactas, Físicas y Naturales, Universidad Nacional de Córdoba, Córdoba, Argentina. 2. Centre d’Ecologie Fonctionnelle et Evolutive (CNRS- UMR 5175) Montpellier, France.

\begin{abstract}
Aвstract. Several studies attempted to find quick and easy methods to assess litter decomposability. We tested three frequently used methods on 6 Mediterranean herbaceous species from different plant families and life forms: (1) 'green leaves traits': traits of living leaves related to the strategies of living plants; (2) 'litter traits': litter respiration during in vitro incubation and initial litter properties; and (3) 'leaf and litter spectral properties': the spectral characteristics (NIR) of green leaves and litter. We analyzed the relationship between these methods and their consistency to assess litter decomposability in the field. Green leaves spectral properties were the most accurate to predict field decomposability, followed by leaf dry matter content (LDMC) and initial content of non-labile compounds. In vitro decomposability marginally correlated with field decomposability. The selection among these predictors may then depend on the instruments available. LDMC is the easiest and least expensive, and is also a constant trait within species. Alternatively, if available, NIR spectra of green leaves and initial litter represent the quickest method for estimating decomposability and litter quality at the same time. Our findings confirm previous evidence that for species from semi-arid systems structural traits like LDMC and non-labile compounds content are important properties controlling species litter decomposability. The validity of our conclusions when a wider range of species is included remains to be tested.
\end{abstract}

[Keywords: NIRS, forbs, grasses, litter decomposition, litter quality, functional markers]

Resumen. Prediciendo la descomponibilidad de la hojarasca: evaluación de caracteres funcionales de hoja, de broza y de propiedades espectrales de seis especies herbáceas del Mediterráneo: Algunos trabajos han explorado métodos fáciles y rápidos de evaluar la decomponibilidad de la broza de grandes conjuntos de especies. Aquí evaluamos tres de los más utilizados en seis especies mediterráneas herbáceas de diferentes familias y formas de vida: (1) 'caracteres de hojas verdes': caracteres de hojas vivas relacionadas a las estrategias de vida de las plantas; (2) 'caracteres de la broza': respiración de la broza durante incubaciones in vitro y propiedades iniciales de la broza; (3) 'propiedades espectrales de las hojas y de la broza': características espectrales (NIR) de las hojas verdes y de la broza. Analizamos las relaciones entre estos métodos y su consistencia para evaluar la tasa de descomposición de la broza en el campo. Las propiedades espectrales de hojas verdes fueron las más precisas para predecir la descomponibilidad a campo, seguidas por el contenido de materia seca de las hojas (LDMC) y el contenido inicial de compuestos no lábiles de la broza. La descomponibilidad in vitro se correlacionó marginalmente con la descomponibilidad a campo. La selección entre los predictores puede depender, entonces, de los instrumentos disponibles. LDMC es el método más económico y fácil de medir para grandes conjuntos de especies que, a su vez, fue constante dentro de las especies analizadas. Alternativamente, en el caso de tener el equipamiento y las calibraciones disponibles, los espectros NIR de las hojas verdes y de la broza inicial representan un método rápido para estimar la descomponibilidad y calidad de la broza al mismo tiempo. Nuestros resultados confirman evidencias previas que para las especies de sistemas semiáridos caracteres estructurales como LDMC y el contenido de compuestos no lábiles son propiedades importantes en el control de la descomponibilidad de la broza. La validez de nuestras conclusiones para un rango mayor de especies debería probarse en futuros estudios.

[Palabras clave: NIRS, hierbas, pastos, descomposición de la broza, calidad de la broza, marcadores funcionales]

\section{INTRODUCTION}

The accelerated transformation of land use and climate associated with global change have renewed interest in the relationships between biodiversity and ecosystem

$\triangle$ nperez@com.uncor.edu processes like decomposition (Norby et al. 2001; Quested et al. 2007; Fortunel et al. 2009). Global change drivers may affect not only the abiotic conditions relevant for litter decomposition but also communities' composition, and therefore litter quality (Cornelissen et al. 1999; Fortunel et al. 2009). 
The understanding of decomposition as a process, as well as the accurate prediction of decomposition dynamics of different species in different ecosystem is essential to evaluate the effects of global change on ecosystem functioning.

There have been several attempts to find quick and easy methods to assess litter decomposability of large sets of species. In a first approach, Aerts \& de Caluwe (1997) compared initial litter respiration rates of different Carex species and long-term litter decomposition rates of the same litter. They concluded that litter mass loss after in vitro incubation was a good predictor of long-term decomposition in the field, and hence this quick and easy method may be a valuable tool in comparative studies of long-term decomposition. However, as only low-lignin Carex species were included in this experiment, the question of whether decomposability of different species with different leaf qualities could also be predicted by in vitro incubation remained unanswered.

A second approach compared traits among widely different sets of species, functional types and families (Cornelissen et al. 1999; Cornwell et al. 2008). This approach showed that most of the litter attributes that affect decomposition seem to be the legacy of living leaves traits (leaf traits) related to protection against the environment (Grime et al. 1996; Cornelissen et al. 1999). Among those leaf traits, the most relevant were specific leaf area (or its underlying components such as leaf density), leaf nitrogen content and leaf carbon-to-nitrogen ratio (Palm \& Rowland 1997; Cornelissen et al. 1999). Among litter traits, decomposition rate was related to chemical quality indices such as total nitrogen $(\mathrm{N})$ or carbon-to-N ratio (Taylor et al. 1989; Aber et al. 1990), lignin-to-N ratio (Melillo et al. 1982), lignin + cellulose content (Aber et al. 1990), lignin + cellulose + hemicelluloses content (Poca et al. 2014) and holocelluloseto-lignocellulose ratio (McClaugherty \& Berg 1987). When species from semiarid habitats are included, structural traits like leaf toughness, leaf thickness, and leaf dry matter content could also be useful indicators of decomposition (Gallardo \& Merino 1993; Cornelissen et al. 1999; Kazakou et al. 2006). This was also recently shown at the community level, where community weighed mean values of leaf traits correlated with community-level decomposability and with field decomposition (Garnier et al. 2004; Quested et al. 2007; Fortunel et al. 2009).
A third approach is based on the use of near infrared reflectance spectroscopy (NIRS). NIRS is a non-destructive and highly precise physical method of characterizing biochemical composition of organic materials, and constitutes a powerful and rapid technique for predicting the biochemical composition of leaves and litter (McLellan et al. 1991; Joffre et al. 1992, 2001; McTiernan et al. 2003). It can also provide insights into the decomposition process (Gillon et al. 1993, 1999; Joffre et al. 2001; Kazakou et al. 2009) or microbial respiration (Fritze et al. 1994).

We tested different methods to predict rates of leaf litter mass loss incubated simultaneously under the same conditions (litter decomposability, Pérez-Harguindeguy et al. 2013), on 6 species belonging to different plant families and life forms (biennial and perennial forbs and perennial grasses, see Table S1 Supplementary Information) from the Mediterranean. We compared: (1) traits of living leaves related to the strategies of living plants; (2) traits of litter: litter respiration and litter mass loss during in vitro incubation, and initial litter quality properties; and (3) leaf and litter spectral properties: the NIR spectral characteristics of green leaves and litters. We analyzed the relationship between these different methods and their consistency as alternative approaches to assess litter decomposability.

\section{Material AND MethodS}

\section{Study area and species selection}

Plant material was collected from the Mediterranean region of southern France, where important changes in land use, mainly agricultural abandonment, have occurred during the twentieth century (Debussche et al. 1999). We selected six herbaceous species occurring along succesional stages following vineyard abandonment, largely differing in leaf traits (cf. Garnier et al. 2004; Kazakou et al. 2006): Picris hieracioides (PH) and Dipsacus fullonum (DF), both biennial forbs which are among the most abundant species 8-15 years after abandonment; Brachypodium phoenicoides $(B P)$ and Bromus erectus (BE), both perennial grasses which are the dominant species in fields abandoned for more than 25 years (Garnier et al. 2004); Inula conyza (IC) and Agrimonia eupatora (AE), perennial forbs, which are subordinate species in fields of intermediate (10-20 years) and late (older than 25 years) successional stages, respectively. This selection included a wide spectrum of plant families and leaf qualities (Table S1). 


\section{Field decomposability}

We collected recently senesced leaves (leaf litter) directly from the plants. Samples of air-dry litters (3-4 g) were placed in polyester net litterbags (16 $x 12 \mathrm{~cm}, 0.5 \mathrm{~cm}$ mesh). All samples were placed directly on the soil surface, slightly covered by the natural litter of the site at the experimental garden of the 'Centre d'Ecologie Fonctionnelle et Evolutive' in Montpellier, France $\left(43^{\circ} 38^{\prime} \mathrm{N}, 3^{\circ} 52^{\prime} \mathrm{E}\right)$. Litterbags were decomposed for 9 months under natural precipitation, insolation and temperature conditions. The mesh size allowed free movement of macrofauna contributing to the natural decomposition process in the field (Cornelissen 1996).

Fifteen litterbags were prepared for each species. Five of them were retrieved every 3 months (6 species $\times 15$ litterbags $=90$ litterbags). The recovered material was carefully cleaned from particles, dried at $50^{\circ} \mathrm{C}$ to constant weight, and weighted to measure litter mass loss after incubation. Additional samples of each species initial litter were also dried at $50^{\circ} \mathrm{C}$ to constant weight to determine the water content of the original litter and to calculate initial oven-dry weights of the materials. The incubation period was enough to reach around $70-80 \%$ of mass loss.

This study was not intended to simulate in situ decomposition of each species in the different successional stages but rather designed to obtain comparable decomposition rates from species of different leaf qualities (Cornelissen 1996; PérezHarguindeguy et al. 2013). For this reason the absolute values of decomposition obtained were not the focus of the test, but the ranking of the species across the methods compared.

\section{In vitro decomposability and litter traits}

Estimations of respiration and mass loss in microcosms conditions were performed by incubating litter samples of the 6 selected species in microcosms as described below. After incubation we measured $\mathrm{C}-\mathrm{CO}_{2}$ release $(\mu \mathrm{gC} / \mathrm{g})$ and dry mass loss (\%) of each sample. The air-dry soil (top $10 \mathrm{~cm}$ from experimental field; red Mediterranean soil, $\mathrm{WHC}=19.41 \%)$ was sieved $(2 \mathrm{~mm})$, homogenized and moistened to $100 \%$ WHC. Fifteen batches of moistened soil (150 g air-dry soil) were put into 15 hermetically sealed vessels for each species. In each vessel we added 1 litterbag (containing $2 \mathrm{~g}$ of litter) and 1 flask with $20 \mathrm{ml} \mathrm{NaOH} 2 \mathrm{~N}$ to trap the $\mathrm{CO}_{2}$ released by respiration during decomposition. The microcosms were incubated at $28^{\circ} \mathrm{C}$ during 6,13 and 23 days (6 species $\times 15$ litterbags $=90$ microcosms with litterbags). Incubation periods, as well as field decomposability periods, were selected according to the results of previous works with similar species (Cortez et al. 1996). The flasks of $\mathrm{NaOH}$ were replaced every two or three days. Respired $\mathrm{CO}_{2}$ captured in the alkali was quantified by flow colorimetry. At the end of each incubation period $(6,13$ and 23 days) we collected five samples of each species to measure dry mass loss due to decomposition, and to compare mass loss with the respiration of the same sample. Additionally to these measurements we measured $\mathrm{C}-\mathrm{CO}_{2}$ released by soil without litter (5 microcosms with $150 \mathrm{~g}$ of soil +1 flask of $\mathrm{NaOH} 2 \mathrm{~N}$ ), and $\mathrm{C}-\mathrm{CO}_{2}$ from the microcosm atmosphere ( 3 blanks) and subtracted these values from the total respiration.

For the determination of initial litter $\mathrm{C}$ and $\mathrm{N}$ by elemental analysis, we measured carbon (C) and nitrogen $(\mathrm{N})$ in each of the 6 species initial litters (2 pooled replicates for each species). Each sample was oven dried for $48 \mathrm{hs}$ at $60^{\circ} \mathrm{C}$, and ground. After grinding, $5 \mathrm{mg}$ of each replicate were measured with an elemental analyzer (Carlo Erba Model EA1108, Milano, Italy).

\section{Leaf traits}

Based on the literature, we selected traits of living leaves known to be associated with major plant strategies (Pérez-Harguindeguy et al. 2013). We measured: (i) specific leaf area (SLA: the ratio of water-saturated leaf area to leaf dry mass), which represents the light-intercepting area per dry mass of leaf, related to net assimilation rate and plant growth rate (Pérez-Harguindeguy et al. 2013 and references therein); (ii) leaf dry matter content (LDMC: the ratio of leaf dry mass to water-saturated fresh mass), a surrogate for leaf tissue dry density, related to nutrient retention within the plant (Pérez-Harguindeguy et al. 2013 and references therein); (iii) nitrogen and carbon concentrations in green leaves. Nitrogen concentration is strongly correlated to the nitrogen-rich compounds involved in the carbon-fixation process, and their relationship with carbon (C-to- $\mathrm{N}$ ratio) has been indicated as a strong predictor of decomposition rates in many studies (Pérez-Harguindeguy et al. 2013 and references therein). Both nitrogen and carbon concentrations were measured on ground material with the elemental analyzer already described.

All leaf traits of green leaves were measured on 4 to 10 individuals ( 2 to 10 leaves per individual) sampled along the successional stages described above, on the youngest, fully expanded, well-lit leaves of each species (cf. Pérez-Harguindeguy et al. 2013 for details on methods), at the spring peak of growth. Only two replicates were used for all traits in Inula conyza. Additional leaf material of comparable characteristics was collected for spectral analysis (see below).

\section{Spectral leaf and litter properties}

The general principles and methodology involved in the NIRS technique can be briefly described as follows (for further details see e.g. Shenk \& Westerhaus 1991a, b). The primary constituents of the organic compounds of plant and animal tissues (i.e., $\mathrm{C}-\mathrm{H}, \mathrm{N}-\mathrm{H}$, and $\mathrm{O}-\mathrm{H}$ bonds) absorb near infrared radiation with wave length between 750 and $2500 \mathrm{~nm}$ (Osborne et al. 1993). Therefore, the spectrum of light that is reflected by a sample contains details on the chemical composition 
(i.e., number and nature of bonds present) of that material (Shenk \& Westerhaus 1991a, b) and, through this chemical composition, of its decomposability (Gillon et al. 1999). To test the intensity of the relationship between a particular absorbance and independent laboratory analysis of a constituent of interest (i.e. \% litter mass loss, $\%$, $\% \mathrm{~N}$ ) statistical analysis are applied. NIR analysis is thus an indirect method that estimates the chemical composition and potential decomposability of a sample by comparing spectra with samples of known chemical composition and decomposability (Joffre et al. 1992; Gillon et al. 1999).

For the litter spectral analyses all litter samples, both initial litter (i.e. fresh leaf litter from the different species) and decomposed litter (leaf litter remaining after field and laboratory incubation), were ground in a cyclone mill through a $1 \mathrm{~mm}$ mesh size and scanned using a near infrared reflectance spectrophotometer (NIRSystems 6500). For each sample, we made 32 scans at 2-nm intervals over a range from 400 to $2500 \mathrm{~nm}$, to produce an average spectrum of 1050 data points. Then, reflectance $(R)$ was converted to absorbance $(A=\log (1 / R))$. Data analysis was conducted using the ISI software system (Shenk \& Westerhaus 1991a).

We first compared the different litters and their spectral and biochemical changes during decomposition between laboratory and field conditions, in order to check if the chemical structure of the litter was affected by both types of incubations in the same way. To do so, a principal component analysis (PCA) was carried out on the spectral data from all litter samples, initial and decomposed litter under the different treatments.

Furthermore, using calibration equations between initial litter spectral properties and its chemistry that were established previously on a large set of initial litters encompassing a very large array of species (Joffre et al. 1992; Gillon et al. 1993, 1999), we predicted initial litter quality for all litters from their spectral properties (specifically: lignin $=$ LIG, cellulose $=$ CEL and hemicellulose $=$ HEM concentrations). We then calculated three litter quality indices relating to the proportions of labile and non-labile compounds, and the relationship between non-labile compounds in plant to test their relevance as litter decomposability indicators (McClaugherty \& Berg 1987; Cortez et al. 1996; Poca et al. 2014): lignin:nitrogen ratio (LIG: $\mathrm{N})$, holocellulose:fiber ratio $(\mathrm{HLQ}=(\mathrm{CEL}+\mathrm{HEM})$ / $(\mathrm{LIG}+\mathrm{CEL}+\mathrm{HEM})$ ) and litter fibre component or sum of non-labile compounds (LCH= LIG+CEL+HEM). The measured values were obtained with standard errors of calibration of $2.8 \%$ for LIG, and $1.7 \%$ for CEL and HEM. Spectrally determined lignin and cellulose contents of Inula conyza were not considered because they fell out of the calibration data sets.

Finally, we also derived a litter decomposability index (LDI) from the initial litter spectral characteristics of the six species studied here, using the calibration established by Gillon et al. (1999). LDI represents the simplest decay descriptor whose calibration by NIRS was accurate, and is expressed as $\mathrm{k}$ value in standard in vitro incubation conditions. LDI index had a standard error of calibration of $0.6 \mathrm{yr}^{-1}$.

The samples of green leaves for the spectral analyses were processed as described for leaf litter samples (dried, ground and scanned as explained above) in order to derive a decomposability index from green leaves (GLDI). The aim of this analysis was to explore whether the green leaves spectra contain information on the decomposability of litter, i.e. whether the spectral data of the green foliage are related to the decay parameters of the litter. Using the spectral data of green foliage, we first calculated Pearson correlations between the spectral absorbance values and field measured litter decay rate (correlogram), and then we developed the calibrations. In NIRS studies, calibration is the process of deriving predictive models that relate the spectra of samples to their reference values (Shenk \& Westerhaus 1996). In this study, calibrations using only six samples with their $\mathrm{k}$ values were not performed to obtain a predictive model (which would need far more replicates) but exclusively to explore if a model could be established between the spectral data from the green leaves and the constant of decomposition $\mathrm{k}$ of their litters. To assess the quality of the model resulting from the calibration, $\mathrm{k}$ values fitted by the model were compared to the measured values that were used to build the model. The calibrations were performed using the partial least squares regression (PLS) method (Shenk \& Westerhaus 1991b). This method uses all the spectral information, unlike stepwise regression type methods that only use a small number of wavelengths (Windham et al. 1989). PLS regression is recognized as a very powerful tool for developing models from spectroscopic data (Shenk \& Westerhaus 1991b). PLS calibrations for in vitro and field $\mathrm{k}$ were then carried out using the first and second derivative data from the whole spectrum $(400-2500 \mathrm{~nm})$ and from the nearinfrared region (1100-2500 $\mathrm{nm}$ ) of the green leaves spectra. After comparison of the results of various treatments, the calibrations that gave the best-fitted $\mathrm{k}$ values were selected (Windham et al. 1989).

\section{Decomposition dynamics and constant of decomposition $(k)$}

On the basis of dry mass loss data during in vitro incubation and during field decomposability we calculated: (1) percentage of mass loss in each period of time and (2) constant of decomposition $k$ for each species following Olson (1963) model:

$$
X t=X 0 e-k t
$$

where $X 0$ and $X t$ are litter dry weight at the beginning of incubation and at time trespectively, $t$ is time in days, and $k$ is the constant of decomposition. For calculation of $k$ we adjusted linear regressions of $\ln (x t / x 0)$ vs. time. We calculated $k$ constant for the complete field incubation (267 days in the 
a

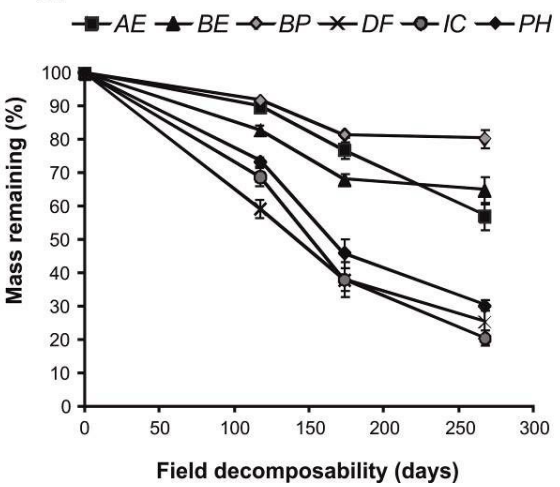

b

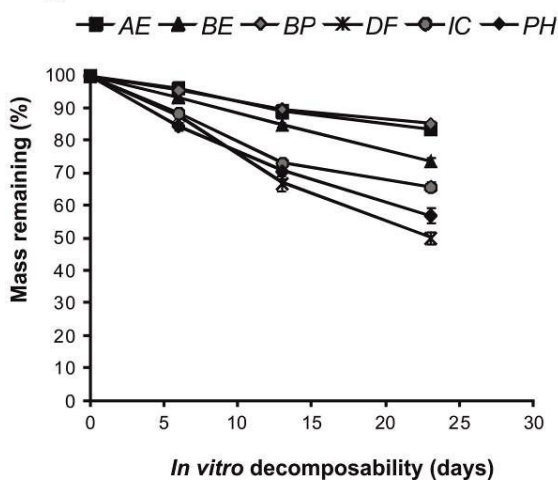

Figure 1. Litter mass remaining (\%) as a function of decomposition time for: (a) field decomposability and (b) in vitro decomposability for the six herbaceous mediterranean species included in this work. $\mathrm{n}=5$ for both field and in vitro incubation. $A E=$ Agrimonia eupatora, $B P=$ Brachypodium phoenicoides, $B E=$ Bromus erectus, $D F=$ Dipsacus fullonum, $I C=$ Inula conyza, $\mathrm{PH}=$ Picris hieracioides.

Figure 1. Peso remanente de la broza (\%) en función del tiempo de (a) la descomponibilidad en el campo y (b) la incubación in vitro para las seis especies mediterráneas herbáceas incluidas en este trabajo. $n=5$ para ambas formas de incubación. Ver nombres en leyenda en inglés.

field $=\mathrm{F} 267 k$ ), and also for all the periods of in vitro incubation (0-6 days in vitro= IV $6 k, 0-13$ days in vitro $=$ IV $13 k$, and 0-23 days in vitro= IV $23 k$ ).

\section{Data analysis}

We used simple regressions to identify the best predictor of field decomposability among mass loss, $\mathrm{CO}_{2}$ release and constant of decomposition $k$ during in vitro incubation, leaf traits and green leaves and litter decomposability index derived from NIRS. We used ANOVA to test differences between species mass loss during both decomposition experiments.

\section{RESULTS}

Most of the variation of living leaves (SLA, LDMC, C, N and C/N) and litter (C, N, C/N) as well as NIRS derived litter quality and decomposability index (LDI and GLDI) can be associated to the successional stage of the sites where the species are characteristic (Table S1). Both dominant ( $\mathrm{PH}$ and $\mathrm{DF}$ ) and subordinate (IC) species from intermediate successional stages are characterized by higher SLA and N content, and lower LDMC in green leaves, and litter with low fibres content. Dominant ( $B P$ and $B E)$ and subordinate species $(A E)$ from late successional stages showed opposite patterns. Leaf litter $\mathrm{N}$ variability among species was much less marked than green leaf $\mathrm{N}$.

\section{Field and in vitro decomposability}

Litter mass loss in the field ranged from $8 \%$ in $B P$, the slowest decomposing species, at 117 days of incubation, to $41 \%$ for $D F$, the fastest decomposing species (Figure 1a). At the end

Table 1. Species decomposability for field incubación after 267 days and for in vitro incubation during 23 days: mass loss and the constant of decomposition $\mathrm{k}$ (and its adjustment to the negative exponential model $\left(\mathrm{R}^{2}\right)$. For in vitro incubation mass loss we also show its association with $\mathrm{CO}_{2}$ release. $A E=$ Agrimonia eupatora, $B P=$ Brachypodium phoenicoides, $B E=$ Bromus erectus, $D F=$ Dipsacus fullonum, IC = Inula conyza, $P H=$ Picris hieracioides. Different letters indicate significant differences $(P<0.05)$ among species \% mass loss according to LSD test. Probability: ${ }^{*}(P<0.05),{ }^{* *}(P<0.01),{ }^{* * *}(P<$ $0.0001)$ and ${ }^{* * * *}(P<0.00001)$.

Tabla 1. Descomponibilidad de las especies para la incubación a campo luego de 267 días y para la incubación in vitro luego de 23 días: \% de pérdida de peso seco y la constante K de descomposición (y su ajuste para el modelo exponencial negativo, $\mathrm{R}^{2}$ ). Para la pérdida de peso seco de la incubación in vitro también mostramos la asociación con la liberación de $\mathrm{CO}_{2}$. Ver detalles en leyenda en inglés.

\begin{tabular}{|c|c|c|c|c|c|c|c|c|}
\hline \multirow[b]{2}{*}{ Species } & \multicolumn{3}{|c|}{ Field incubation } & \multicolumn{5}{|c|}{ In vitro incubation } \\
\hline & $\begin{array}{c}\text { Mean mass } \\
\text { loss (\%) }\end{array}$ & $k\left(\right.$ day $\left.^{-1}\right)$ & $\mathrm{R}^{2}$ & $\begin{array}{l}\text { Mean mass } \\
\text { loss }(\%)\end{array}$ & $k\left(\right.$ day $\left.^{-1}\right)$ & $\mathrm{R}^{2}$ & $\begin{array}{c}\mathrm{C}-\mathrm{CO}_{2} \\
(\mu \mathrm{gC} / \mathrm{g})\end{array}$ & $\begin{array}{c}\mathrm{CO}_{2} \text {-to-mass } \\
\text { loss }\left(R^{2}\right)\end{array}$ \\
\hline$\overline{\mathrm{AE}}$ & $43 c$ & 0.002 & $0.77^{* * *}$ & $16 \mathrm{~d}$ & 0.008 & $0.78^{* * *}$ & 65 & $0.96^{* * * *}$ \\
\hline$B P$ & $20 \mathrm{~d}$ & 0.001 & $0.62 * *$ & $15 \mathrm{~d}$ & 0.006 & $0.89^{* * *}$ & 76 & $0.94^{* * * *}$ \\
\hline$B E$ & $35 c$ & 0.002 & $0.61 * *$ & $26 c$ & 0.013 & $0.93^{* * *}$ & 39 & $0.94^{* * * *}$ \\
\hline$D F$ & $74 \mathrm{a}$ & 0.006 & $0.76^{* * *}$ & $50 \mathrm{a}$ & 0.032 & $0.93^{* * *}$ & 143 & $0.91^{* * * *}$ \\
\hline IC & $79 a$ & 0.007 & $0.82 * * *$ & $34 \mathrm{~b}$ & 0.017 & $0.91 * * *$ & 108 & $0.87^{* * * *}$ \\
\hline $\mathrm{PH}$ & $70 \mathrm{~b}$ & 0.005 & $0.84^{* * *}$ & $43 \mathrm{a}$ & 0.023 & $0.88^{* * *}$ & 124 & $0.93 * * * *$ \\
\hline
\end{tabular}


a

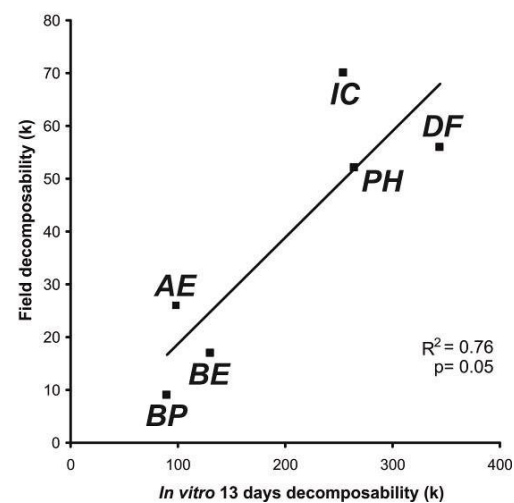

b

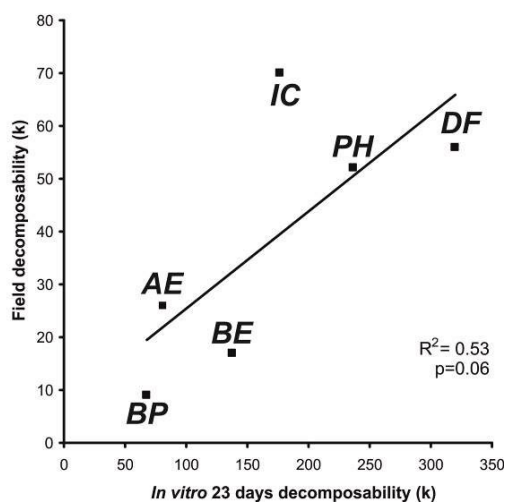

Figure 2. Regressions between the constant of decomposition $\mathrm{k}$ for field decomposability and the constant of decomposition $\mathrm{k}$ for in vitro decomposability after: (a) 13 and (b) 23 days of incubation. $A E=$ Agrimonia eupatora, BP= Brachypodium phoenicoides, $B E=$ Bromus erectus, $D F=$ Dipsacus fullonum, $I C=$ Inula conyza, $P H=$ Picris hieracioides .

Figure 2. Regresiones entre la constante $\mathrm{K}$ de descomposición para la descomponibilidad a campo y la descomponibilidad in vitro luego de: (a) 13 y (b) 23 días de incubación. Ver nombres en leyenda en inglés.

of the incubation (267 days) mass loss ranged from $20 \%$ for BP to $79 \%$ for IC. Mass loss of all species fitted the exponential model of decomposition (Table 1). ANOVA indicated highly significant differences $(P<0.0005)$ in mass loss between species (Table 1).

In vitro litter mass loss ranged from $4 \%$ in $A E$ the slowest decomposing species at 6 days of incubation, to $16 \%$ for $P H$ the fastest (Figure 1b). At the end of the incubation (23 days) the mass loss ranged from $15 \%$ for $B P$ to $50 \%$ for DF. Mass loss of all species after in vitro incubation also fitted the exponential model of decomposition and was strongly correlated to $\mathrm{CO}_{2}$ release during incubation (Table 1). ANOVA indicated highly significant differences $(P<0.0005)$ in mass loss between all species.

The decay rate $k$ calculated after the complete field incubation period was more strongly associated to $k$ value at 13 days of in vitro incubation $\left(R^{2}=0.76, P=0.050\right.$, Figure $\left.2 \mathrm{a}\right)$,
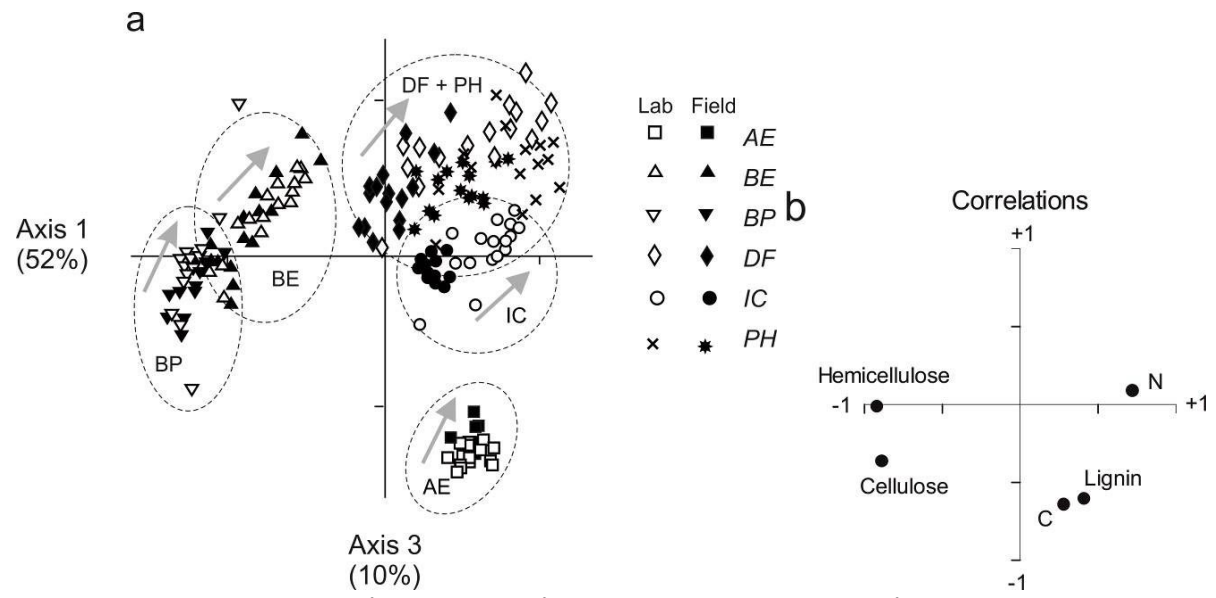

Figure 3. (a) Axes 1 and 3 (see text) of the PCA performed on the spectral data from all litter samples (both initialundecomposed leaf litter and all retrieval dates after in vitro and field incubation). The grey arrows indicate the approximate direction of change in spectral properties from initial and less decomposed samples to samples at the final incubation retrieval dates. (b) Graphical representation of Pearson correlation coefficients among chemical descriptors of samples and scores of the same samples along axes 1 and 3 of the PCA. AE=Agrimonia eupatora, BP=Brachypodium phoenicoides, $B E=$ Bromus erectus, $D F=$ Dipsacus fullonum, $I C=I n u l a$ conyza, $P H=$ Picris hieracioides.

Figure 3. (a) Ejes 1 y 3 (ver en el texto) del PCA de los datos espectrales de todas las muestras de broza (tanto las iniciales-sin descomponer, como las muestras descompuestas provenientes de las incubaciones in vitro y a campo). Las flechas grises indican la dirección aproximada del cambio en las propiedades espectrales desde las muestras iniciales (y menos descompuestas) hacia las muestras al final del período de incubación. (b) Representación gráfica de los coeficientes de correlación de Pearson entre descriptores químicos de todas las muestras en el plano definido por los ejes 1 y 3 del PCA. Ver nombres de especies en leyenda en inglés. 
a

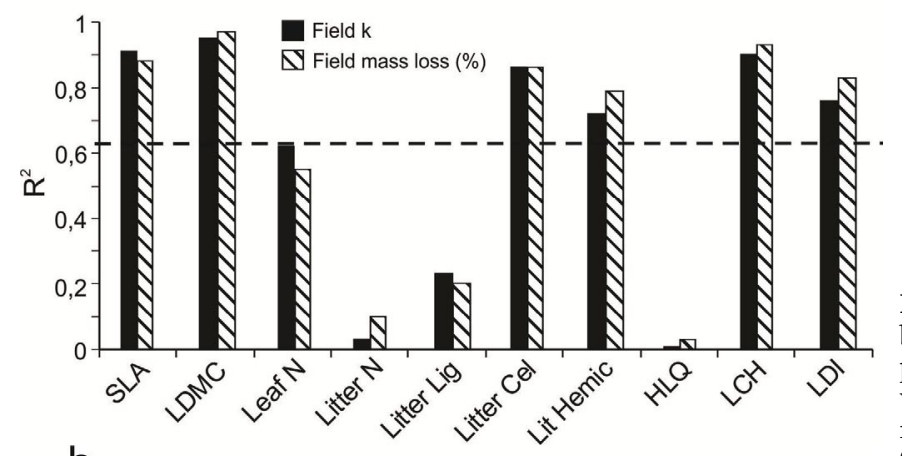

b

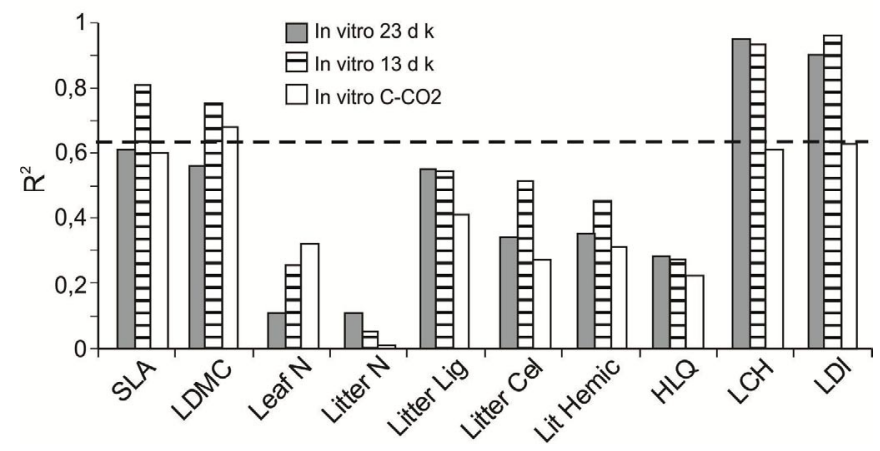

Figure 4. Comparison of regression coefficients between: (a) field decomposability and its predictors and (b) in vitro decomposability with the same variables. The dashed line represents the $R^{2}$ value from which $P<$ $0.05 . \mathrm{SLA}=$ specific leaf area, $\mathrm{LDMC}=$ leaf dry matter content, $\mathrm{C}=$ carbon content, $\mathrm{N}=$ nitrogen content, $\mathrm{C}$ to $\mathrm{N}=$ carbon-to-nitrogen ration, $\mathrm{LIG}=$ litter lignin content, $\mathrm{CEL}=$ litter cellulose content, HEM= litter hemicellulose content, NIRS LDI= near infrared spectroscopy predicted litter decomposability index, NIRS GLDI= near infrared spectroscopy predicted green leaf decomposability index.

Figure 4. Comparación de los coeficientes de regresión entre: (a) la descomponibilidad a campo y sus predictores y (b) la descomponibilidad in vitro con las mismas variables. La línea punteada representa el valor de $R^{2}$ donde $P<0.05$. Ver siglas en leyenda en inglés. than to in vitro decomposability after the whole incubation period ( 23 days, $R^{2}=0.53, P=0.06$, Figure $2 b$ ). The same pattern was found for mass loss, where mass loss in the field after 267 days was more strongly associated to mass loss after $13\left(R^{2}=0.83, P=0.005\right.$, Figure S1a) than to mass loss after 23 days of in vitro incubation $\left(R^{2}=0.71, P=0.05\right.$, Figure $\left.S 1 b\right)$.

\section{PCA on NIR spectral data from all litter samples}

For the PCA performed on the spectral data from all samples together (initial and decomposing litter samples from in vitro and field decomposition), the first 3 axes accounted for $87 \%$ of the spectral variability. PCA axis 1 accounted for $52 \%$ of variability and PCA axis 3 for $10 \%$ (Figure 3a). Although axis 2 explained more variability than axis $3(25 \%$ of spectral variability versus $10 \%$ respectively) it was not considered in the analysis (and it is not shown as part of the graph) because this axis was not associated to any of the variables measured, so it may be describing spectral properties different from the ones typically related to decomposition. There is a general direction of change in spectral qualities during decomposition (graphically shown by grey arrows on Figure 3a). Notwithstanding this general pattern, the PCA shows that during both field and in vitro incubation, each species or group of species conserved the spectral attributes distinguishing from the others. This indicates that over the incubation periods studied, these different litters did not converged into a common biochemical composition, even for species that lost about $80 \%$ of their initial litter mass. Correlations of chemical compounds concentration in initial and decomposed litter with PCA axes indicate that litters with high concentration of hemicellulose and cellulose and low $\mathrm{N}$ content (the grasses $B P$ and $B E$ ) were separated from all other species along axis 1 (Figure $3 b$ ); while litters rich in $\mathrm{N}(P H, D F, I C$ from intermediate successional stages) are separated from the lignin-rich $A E$ (forb species from late successional stages) along axis 3. PCA also showed that as decomposition proceeds (and litters tend to shift from the lower and left extreme of the graph to the opposite extreme as shown in Figure 3a) N, lignin and C contents grow in relation to cellulose and hemicellulose contents (Figure 3b).

\section{Field decomposability and its predictors}

Among leaf traits LDMC was the best predictor of field decomposability, explaining $94 \%$ of the variance of field $k(P=0.0009$, Figure 4a and Figure S2a). This trait was also a good 
predictor of in vitro decomposability after 13 days of incubation (explaining $68 \%$ of its variance, $P=0.03$ ), as well as $\mathrm{CO}_{2}$ release after the whole period (explaining $68 \%$ of its variance, $P=0.04$ ). However, LDMC failed to predict 23 days in vitro incubation (Figure 4b). SLA was also a good predictor of field decomposability explaining about $90 \%$ of field mass loss and field $k$ variance (Figure $4 \mathrm{a}$ ).

Among litter traits, both directly-measured (C and N) and NIRS-estimated (lignin, cellulose and hemicellulose), the best predictor of field and in vitro decomposability was the sum of non-labile compounds in litter (LCH) (Figure 4). $\mathrm{LCH}$ explained $87 \%$ of variability of field $k$ at 267 days (Figure $4 a$ and Figure S2b), and $93 \%$ of variability of in vitro $k$ at 23 days (Figure $4 b)$. $\mathrm{LCH}$ was also associated to $\operatorname{LDMC}\left(R^{2}=\right.$ 0.75, $P=0.004)$.

Among litter spectral properties NIRS predicted litter decomposability index (LDI) was highly associated to decomposability in the field (Figure 4a) as well as with decomposability in the lab (Figure $4 \mathrm{~b}$ ). Accordingly, NIRS predicted LDI was also highly correlated with LCH $(\mathrm{r}=0.99, \mathrm{p}=0.002)$ and LDMC $(r=0.90, P=0.04)$.

Absorbance of green leaves in several spectral regions of the visible $(400-1100 \mathrm{~nm})$ and of the near-IR (1100-2500 nm) domains was significantly correlated with field constant of decomposition $k$. The best model resulting from the NIRS calibration on field $k$ from the green leaves was obtained using the second derivative of the spectral data of the near Infrared region (1100-2500 nm). The values of $k$ fitted by the model (Green Leaves Decomposability Index, GLDI) were close to the measured values in the field (Figure S2c), and the best predictor of field decomposability among all considered $\left(R^{2}=0.98, P=0.0004\right.$, Figure $4 \mathrm{a}$ and Figure S2c).

\section{DISCUSSION}

Can short-term in vitro decomposability be used to estimate field decomposability in herbaceous plants?

For the species considered in this study in vitro incubation was only a weak predictor of field decomposability (Figure 2, and Figure S1), and only the first periods of incubation were significantly associated to mass loss in the field. Given that in vitro mass loss and $\mathrm{CO}_{2}$ release were strongly related these conclusions also hold for the last mentioned variable. This may indicate that in vitro incubation cannot be a trustable surrogate for estimating decomposability in the field, or that its predictability power varies according to the period of incubation selected (in our study field decomposability was more advanced than in vitro decomposability). In spite of this weak relationship, the PCA of all samples indicated that the spectral attributes of species or groups of species under both methods were highly similar (Figure 3) suggesting that in vitro incubation may in fact give an insight into the biochemical transformation occurring in litter during field decomposability. This also indicates that litter decomposability in laboratory conditions appears quite representative of the decay processes in the field. This somehow contradictory results (weak correlation but similar spectral patterns) may indicate that in vitro decomposability standardized protocols need to be tested across a wider set of species, and across different controlled incubation conditions to constitute a more accurate estimator of field decomposability.

\section{Are field and in vitro decomposability controlled by the same leaf traits in herbaceous plants?}

Our results indicate that both field and in vitro decomposability are controlled by general indexes of leaf or litter quality. It is also evident that, as pointed out in previous studies (Grime et al. 1996; Cornelissen et al. 1999; Kazakou et al. 2006, among others), some of the attributes associated with the functioning of living leaves are conserved in senescent leaves, and affect the properties of the litter. Remarkably, the traits more strongly linked to decomposition are those related to physical attributes of the leaves, like leaf dry matter content and the amount of nonlabile compounds in litter (Figure S2). These findings confirm previous works on species from various growth forms from semi-arid habitats (Gallardo \& Merino 1993; Cornelissen et al. 1999). It is particularly noteworthy that leaf dry matter content, a simple and easy to measure trait, constitutes a very good indicator of litter constant of decomposition $k$ and also of the relationship between the different structural components of the leaf. Leaf dry matter content is an index of the amount of mesophyll (water $+\mathrm{CO}_{2}$ fixation) vs. structural compounds (fibers, lignin, cellulose, hemicellulose, etc.) (cf. Garnier \& Laurent 1994). A high value corresponds to a low proportion of mesophyll and epidermis 
(light tissues) and a high proportion of vascular tissues and sclerenchyma (dense tissues) (Dijkstra \& Lambers 1989; Garnier \& Laurent 1994). In terms of chemical composition, high values correspond to leaves rich in (hemi)cellulose, insoluble sugars and lignin (Poorter \& Berkotte 1992) as confirmed by the strong association between leaf dry matter content and non-labile compounds in litter in the species of our study. Leaf dry matter content is related to leaf longevity (Ryser \& Urbas 2000; Al Haj Khaled et al. 2005), which in turns is one of the components of nutrient conservation together with nutrient resorption. For the species considered in our work, this relationship between leaf dry matter content or non-labile compounds in litter vs. water or labile compounds seems to be one of the main determinants of constant of decomposition $k$ both in vitro and in field decomposability. In other words, more 'strongly-built' leaves that tend to conserve resources more efficiently tend to decompose more slowly, while 'tender' leaves, that tend to acquire resource more rapidly, decompose more quickly. This provides further evidence that initial litter properties such as non-labile compounds are strongly controlled by attributes of living leaves such as leaf dry matter content (specific leaf area to a lesser extent).

\section{Can initial leaf and litter spectral characteristics predict in vitro and field decomposability in herbaceous plants?}

Our results provide new evidences about the potential of NIRS not only to predict the chemical composition of the litter (in our case non-labile compounds) but also to express its quality or potential decomposability both in the short and medium term (Figure S1), when about half of the litter mass still remains (Gillon et al. 1999; Joffre et al. 2001). NIRS then provides a rapid and non-destructive method for directly quantifying litter quality. Moreover, we found direct relationships between the spectral data of the green leaves and the constant of decomposition $k$ of the litter. The correlations found between the absorbance in several spectral regions and field constant of decomposition $k$ show that a part of the spectral information from the green leaves is directly related to the labile or resistant fractions remaining in the litters and controlling their decay rate. NIRS seems to have the potentiality of correlating the medium-term decomposability of the litter not only with the spectral characteristics of the litter (Gillon et al. 1999) but also with the spectral characteristics of the green leaves This new result is promising but it must be tested on larger sets of species to be generalized. The association of initial litter NIR spectra to nonlabile compounds and leaf dry matter content constitutes also an evidence of the link between functional leaf traits and decomposition over a wide range of species and life forms (Cornelissen et al. 1999; Cornwell et al. 2008). Based on these results we could expect that NIRS would constitute a valuable method to understand the linkages between leaf and litter processes. In other words, our result provide additional validation to this method, in this particular case tested on herbaceous species, as an integrative tool to both scale down from the leaf level to its individual structure and biochemical components, and scale up from the leaf level to the whole plant and functional types (Gillon et al. 1999; Quested et al. 2007; Kazakou et al. 2009; Fortunel et al. 2009).

\section{CONCLUSIONS}

Among the three approaches tested, green leaves spectral properties seems to be the more accurate to predict field decomposability on the herbaceous species considered, followed by leaf dry matter content and finally litter initial non-labile compounds. In vitro decomposability was only marginally correlated with field decomposability, and varied with time of incubation. The selection among these predictors will depend on the objectives of the work, and the instruments available. Leaf dry matter content is the easiest and least expensive to measure if we want to estimate potential decomposition of a large set of species, and has also been indicated as a very constant trait. If the technological device with its associated calibration data base is available, NIR spectra of green leaves and initial litter represent the quickest method for estimating potential decomposition and litter quality at the same time over a wide range of species with different litter qualities.

Overall, our findings confirm previous evidence that for species from semi-arid systems, structural traits like leaf dry matter content (or specific leaf area to a lesser extent), and non-labile compounds content are important properties controlling species litter decomposability. How this holds compared to litter $\mathrm{N}$ content or $\mathrm{C} / \mathrm{N}$ ratio when a wider range of species is included remains to be tested. 
Acknowledgements: This research was part of the Project 'Land-use effects over functional biodiversity and ecosystem processes: a comparative approach' (A00B03, Argentine-French Cooperation Program for Scientific and Technologic Research from the Secretary for the Technology, Science and Production-Argentina, and the Centre National de la Recherche Scientifique-France). This work was also funded by PICT Conicet 8148 and PICT 25712. We are grateful to the staff of the CEFE for their assistance with the experiments and measurements and to AM Cingolani and PA Tecco for their comments on an earlier version of this manuscript. We also thank two anonymous reviewers whose comments markedly improved the manuscript.

\section{REFERENCES}

Aber, JD; JM Melillo \& CA McClaugherty. 1990. Predicting long-term patterns of mass loss, nitrogen dynamics, and soil matter formation from initial fine litter chemistry in temperate forest ecosystems. Canad. J. Bot., 68:2201-2208.

Aerts, R \& H de CALuwe. 1997. Initial litter respiration as indicator for long-term leaf litter decomposition of Carex species. Oikos, 80:353-361.

Al Haj Khaled, R; M Duru; JP Theau; S Plantereux \& P CRUz. 2005. Variation in leaf traits through seasons and $\mathrm{N}$-availability levels and its consequences for ranking grassland species. J. Veg. Sci., 16:391-398.

CORNELISSEN, JHC. 1996. An experimental comparison of leaf decomposition rates in a wide range of temperate plant species and types. J. Ecol., 84:573-582.

Cornelissen, JHC; N Pérez-Harguindeguy; S Díaz; JP Grime; B MarZANO; M CABIDO; F VendRAMINI \& B CERABOlini. 1999. Leaf structure and defence control litter decomposition rate across species and life forms in regional floras of two continents. New Phytol., 143:191-200.

Cornwell, WK; JHC Cornelissen; K Amatangelo; E DORREPAAL; VT EVINER ET AL. 2008. The leaf economic trait spectrum drives litter decomposition rates in regional floras worldwide. Ecol. Lett., 11:1065-1071.

Cortez, J; J Demard; P Bottner \& L Jocteur Monrozier. 1996. Decomposition of Mediterranean leaf litters: a microcosm experiment investigating relationships between decomposition rates and litter quality. Soil Biol. Biochem., 28:443-452.

Debussche, M; J Lepart \& A Dervieux. 1999. Mediterranean landscapes changes: evidence from old postcards. Global Ecol. Biogeogr., 8:3-15.

DiJKSTRA, P \& H LAMBERS. 1989. Analysis of specific leaf area and photosynthesis of two 7 inbred lines of Plantago major differing in relative growth rate. New Phytologist, 113:283-290.

Fortunel, C; E Garnier; R Joffre; E KaZAKou; H Quested ET AL. 2009. Leaf traits capture the effects of land use changes and climate on litter decomposability of grasslands across Europe. Ecology, 90:598-611.

Fritze H; P JÄRVINEN \& R HiukKA. 1994. Near-infrared characteristics of forest humus are correlated with soil respiration and microbial biomass in burnt soils. Biol. Fert. Soils, 18:80-82.

Gallardo, A \& J Merino. 1993. Leaf decomposition in 2 Mediterranean ecosystems of Southwest Spain influence of substrate quality. Ecology, 74:152-161.

GARNIER, E \& G LAURENT. 1994. Leaf anatomy, specific mass and water content in congeneric annual and perennial grass species. New Phytol., 128:725-736.
Garnier, E; J Cortez; G Billès; ML Navas; C Roumet et AL. 2004. Plant functional markers capture ecosystem properties during secondary succession. Ecology, 85: 2630-2637.

Gillon, D; R Joffre \& P Dardenne. 1993. Predicting the stage of decay of decomposing leaves by near-infrared reflectance spectroscopy. Canad. J. Forest Res., 23:25522559.

Gillon, D; R Joffre \& A Ibrahima. 1999. Can litter decomposability be predicted by near infrared reflectance spectroscopy? Ecology, 80:175-186.

GRIME, JP; JHC CORNELISSEN; K ThOMPSON \& JG Hodgson. 1996. Evidence of a causal connection between antiherbivore defence and the decomposition rate of leaves. Oikos, 77:489-494.

Joffre, R; D Gillon; P DARDENNE; R AgneEsSENS \& R Biston. 1992. The use of near-infrared reflectance spectroscopy in litter decomposition studies. Ann. Sci. For., 49:481488 .

Joffre, R; GI Ågren; D GILlon \& E BosattA. 2001. Organic matter quality in ecological studies: theory meets experiment. Oikos, 93:451-458.

Kazakou, E; F Vile; B Shipley; C Gallets \& E Garnier. 2006. Co-variations in litter decomposition, leaf traits and plant growth in species from a Mediterranean oldfield succession. Func. Ecol., 20:21-30.

Kazakou, E, C Violle; C Roumet; C Pintor; O Gimenez \& E GARNIER. 2009. Litter quality and decomposability of species from a Mediterranean succession depend on leaf traits but not on nitrogen supply. Ann. bot., 104: 1151-1161.

MCClaugherty, CA \& B Berg. 1987. Holocellulose, lignin and nitrogen levels as rate-regulating factors in late stages of forest litter decomposition. Pedobiologia, 30: 101-112.

Mclellan, TM; M Martin; JD Aber; JM Melillo; KJ Nadelhoffer \& B Deway. 1991. Comparison of wet chemistry and near infrared reflectance measurements of carbon fraction chemistry and nitrogen concentration of forest foliage. Canad. J. Forest Res., 21:1689-1694.

McTiernan, KB; MM Côuteaux; B Berg; MP BerG; R Calvo DE ANTA ET AL. 2003. Changes in chemical composition of Pinus sylvestris needle litter during decomposition along a European coniferous forest climatic transect. Soil Biol. Biochem., 35:801-812.

Melillo, JM; JD Aber \& JF Muratore. 1982. Nitrogen and lignin control of hardwood leaf litter decomposition dynamics. Ecology, 63:571-584.

Norby, RJ; MF Cotrufo; P Ineson; EG O’NeIll \& JG CanAdell. 2001. Elevated $\mathrm{CO}_{2}$, litter chemistry, and decomposition: a synthesis. Oecologia, 127:153-165.

Olson, JS. 1963. Energy storage and the balance of producers and decomposers in ecological systems. Ecology, 44:322-331.

Osborne, BG; T Fearn \& PH Hindle. 1993. Practical NIR Spectroscopy with Applications in Food and Beverage Analysis. Longman Scientist and Technical, Harlow, UK. 277 pp. 351-364.

PALM, CA \& AP Rowland. 1997. A minimum dataset for characterization of plant quality for decomposition. In: Cadisch. G., Giller K.E. (Eds.), Driven by Nature: plant litter quality and decomposition. CAB InternationalUniversity Press. pp 379-392.

Pérez-Harguindeguy, N; S Díaz; E Garnier; S Lavorel; H Poorter; P Jaureguiberry et AL. 2013. New handbook for standardised measurement of plant functional traits worldwide. Aust J Bot., 61:167-234. 
Poca, M.; N Pérez-Harguindeguy; MV Vaieretti \& AM Cingolani. 2014. Descomposición y calidad físicoquímica foliar de 24 especies dominantes de los pastizales de altura de las sierras de Córdoba, Argentina. Ecología Austral, 24:249-257.

PoOrter, H \& M Bergkotte. 1992. Chemical composition of 24 wild species differing in 14 relative growth rate. Plant, Cell E Environment, 15:221-229.

Quested, H; O ERIKSSON; C Fortunel \& E Garnier. 2007. Plant traits relate to whole-community litter quality and decompositon following land use change. Func. Ecol., 21:1016-1026.

RYSER, P \& P URBAs. 2000. Ecological significance of leaf life span among Central European grass species. Oikos, 91:41-50.

SHENK, JS \& MO WESTERHAUS. 1991a. ISI NIRS-2 software for near-infrared instruments. Infrasoft International.

SHenk, JS \& MO Westerhaus. 1991b. Population definition, sample selection, and calibration procedures for nearinfrared reflectance spectroscopy. Crop Sci., 31: 469-474.

Shenk, JS \& MO Westerhaus. 1996. Calibration the ISI way. In: Davies A.M.C., Williams P., (Eds.), Near infrared spectroscopy: the future waves. NIR publications. pp 198-202.

TAYLOR, BR; D PARKINSON \& WFJ PARSONS. 1989. Nitrogen and lignin content as predictors of litter decay rates: a microcosm test. Ecology, 70: 97-104.

WindHAM, WR; DR Mertens \& FE II Barton. 1989. Protocol for NIRS calibration: sample selection and equation development and validation. In: Marten G.C. Shenk J.S., Barton. F.E. II (Eds.), Near infrared re ectance spectroscopy: analysis of forage quality. Agricultural handbook 643, US Department of Agriculture. pp 96-103. 
a

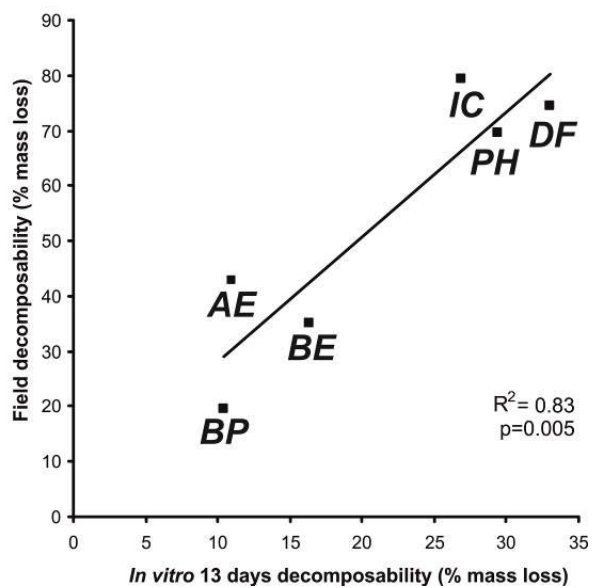

b

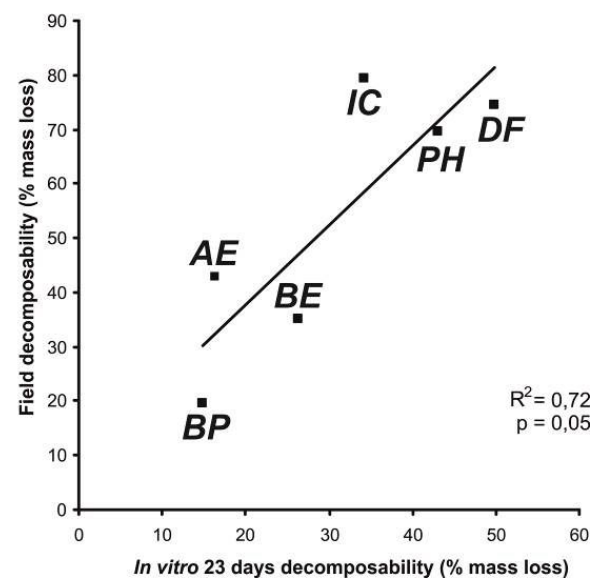

Figure S1. Regression between \% field mass loss and \% in vitro mass loss after: (a) 13 and (b) 23 days of incubation. Regression coeficients $\left(\mathrm{R}^{2}\right)$ and $\mathrm{P}$-value of significance are indicated in the figures. $A E=$ Agrimonia eupatora, $B P=$ Brachypodium phoenicoides, $B E=$ Bromus erectus, $D F=$ Dipsacus fullonum, $I C=$ Inula conyza, $P H=$ Picris hieracioides.

Figure S1. Regresión entre el \% de pérdida de peso seco a campo e in vitro luego de (a) 13 y (b) 23 días de incubación. En las figuras se indican los coeficientes de regresión $\left(\mathrm{R}^{2}\right)$ y los $\mathrm{P}$-valores de significancia. $A E=$ Agrimonia eupatora, $B P=$ Brachypodium phoenicoides, $B E=$ Bromus erectus, $D F=$ Dipsacus fullonum, IC=Inula conyza, $P H=$ Picris hieracioides.
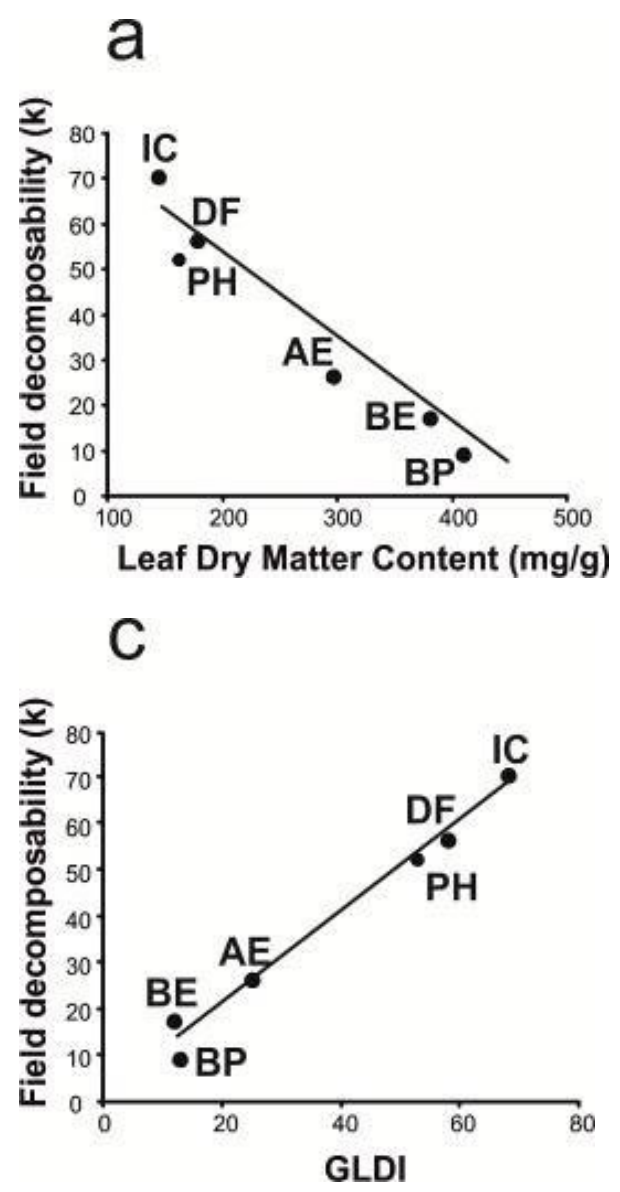

b

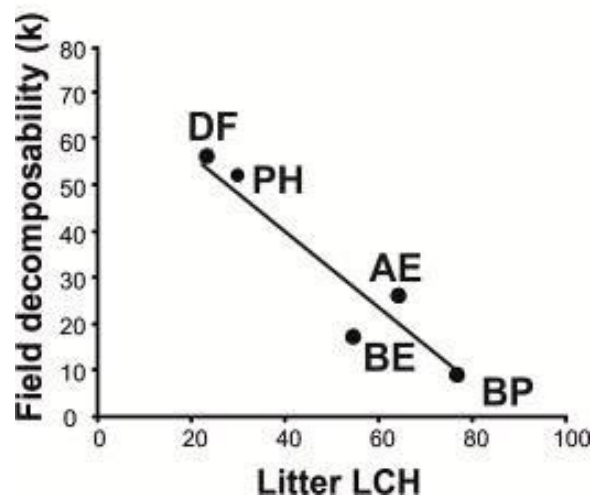

Figure S2. Relationship between the constant of decomposition $\mathrm{k}$ for field decomposability and the best predictor of: (a) leaf (LDMC: leaf dry matter content), (b) litter (LCH: sum of non-labil compounds) and (c) spectral properties (GLDI: green leaf decomposability index). $A E=$ Agrimonia eupatora, $B P=$ Brachypodium phoenicoides, $B E=$ Bromus erectus,$D F=$ Dipsacus fullonum,$I C=I n u l a$ conyza, $\mathrm{PH}=$ Picris hieracioides.

Figure S2. Relación entre la constante K de descomposición de la descomponibilidad a campo y el mejor predictor de: (a) las hojas verdes (LDMC: contenido de materia seca de hoja), (b) la broza (LCH: suma de compuestos no lábiles) y (c) propiedades espectrales (GLDI: índice de descomponibilidad de las hojas verdes). $A E=$ Agrimonia eupatora, $B P=$ Brachypodium phoenicoides, $B E=$ Bromus erectus, $D F=$ Dipsacus fullonum, $I C=$ Inula conyza, $P H=$ Picris hieracioides. 